\title{
Comparison of Conventional and Rapid Methods for Salmonella Detection in Artisanal Minas Cheese
}

\author{
Gardênia M. S. C. Mata ${ }^{1} \&$ Maria Cristina D. Vanetti ${ }^{1}$ \\ ${ }^{1}$ Departament of Microbiology, Federal University of Viçosa, Viçosa, Brazil \\ Correspondence: Universidade Federal de Viçosa, Departamento de Microbiologia, Avenida PH Rolfs, s/n, \\ Campus Universitário, Viçosa, MG 36570-000, Brasil. Tel: 55-31-3899-2954. E-mail: mvanetti@ufv.br
}

Received: March 27, 2012

Accepted: April 16, 2012 Online Published: July 2, 2012

doi:10.5539/jfr.v1n3p178

URL: http://dx.doi.org/10.5539/jfr.v1n3p178

\begin{abstract}
Artisanal cheeses traditionally produced from raw milk have a diverse microbiota and, due the varied changes that occur in this type of food matrix during the maturation, pathogens detection's may be impaired. In this study, the conventional method established by ISO 6579:2005 to evaluate the presence of Salmonella was compared with two alternative rapid methods, PCR-BAX ${ }^{\circledR}$ (DuPont) and VIDAS ${ }^{\circledR}$-SLM (BioMérieux), to analyze artisanal Minas cheese, a typical Brazilian product. Salmonella was not detected by conventional or PCR-BAX ${ }^{\circledR}$ in 63 artisanal Minas cheese samples analyzed. Although highly specific and accurate, the immunoassay $\left(\right.$ VIDAS $^{\circledR}$-SLM) presented $3.17 \%$ of false positives. Good manufactures practices were absent in some producers of Minas artisanal cheese and, the fact of Salmonella was not detected in analyzed samples should be related with presence of high and diverse endogenous microbiota, including approximately, $10^{7} \mathrm{CFU}_{\mathrm{g}}{ }^{-1}$ of lactic bacteria, and a low $\mathrm{pH}$ and water activity, conditions that can minimize pathogens growth, provide cellular injury and hamper the recovery strategies.
\end{abstract}

Keywords: Salmonella, artisanal Minas cheese, PCR-BAX ${ }^{\circledR}$, VIDAS ${ }^{\circledR}$-SLM

\section{Introduction}

Artisanal cheeses are appreciated around the world and constitute a group of specialty cheese whose manufacture is characterized by small scale and limited volume production. These cheeses are manufactured in farmhouses following traditional techniques, without the deliberate addition of selected starter cultures (Randazzo, Caggia, \& Neviani, 2009) and are generally made from raw milk. Besides their cultural, social and economical significance these cheeses are recognized to have great microbial biodiversity, which is generally found at both genus and species level, associated with varied changes that occur in this food matrix during the maturation. High microbial loading was expected in artisanal products that were manufacturing without the observation of good manufactured practices (GMP) and this diverse contamination could promote pathogens inhibition. However, in the wake of food scares in recent decades, raw-milk cheeses have often been categorized as "risky" food (West, 2008) and outbreaks involving pathogens as Salmonella, Listeria monocytogens and Staphylococcus aureus have been associated with the consumption of these cheeses (Hall \& French, 2011).

Salmonella is a food-borne pathogen influencing on food safety and public health around the world. According to Scallan et al. (2011), Salmonella is the second major cause of foodborne disease acquired in the United States and leads episodes of hospitalization and death. Hall and French (2011) evaluated reports on case material dating from January 2000 up to December 2010, in which raw milk or raw milk cheeses were implicated in 772 clinical cases and two deaths due contamination by Salmonella.

The various safety management tools of the worldwide food industry, such as the Hazard Analysis and Critical Control Points (HACCP), use microbiological analyses to monitor emerging risks (Vanne, Karwoski, Karppinen, \& Sjiiberg, 1996). In Brazil, pathogens such as Salmonella sp. must be absent in 25 grams of cheese (Brazil, 2001). In contrast, European legislation mandates a stricter criterion for Salmonella sp., which must be absent in one gram of the same type of product (Directive 92/46/EEC). As a result, a small amount of the pathogen must be detected quickly and securely to avoid damage and legal repercussions generated by contaminated food.

Conventional culture methods for Salmonella detection in foods consist of a series of steps that include nonselective enrichment, selective enrichment, and selective/differential plating and, finally, morphological, 
biochemical and serological confirmation as described in ISO 6579:2005 method (International Standards Organization, 2005).This standardized classical culture method is rather sensitive and quite inexpensive, but it requires at least, three working days to produce a negative result and five to ten working days for a confirmed positive result. Nevertheless, it is still in use by many labs, especially by regulatory agencies, because it is harmonized method, looked at as the "gold standards" in food diagnostics (Jasson, Jacxsens, Luning, Rajkovic, \& Uyttendaele, 2010). Although reliable and officially approved, the conventional methods for the detection of microorganisms in foods require a long period of time to obtain results. Moreover, due to environmental factors, variations in gene expression of microorganisms can occur and may affect the discriminatory power of biochemical tests. Furthermore, viable but nonculturable cells are not detected by the conventional methodology (Malorny et al., 2003).

Alternative and rapid methodologies for the detection of Salmonella in foods are attractive and allowing convenience, flexibility and potential for automation (Oslen, 2000; Koyuncu, Andersson, \& Häggblom, 2010). Molecular methods designed for targeting Salmonella DNA by conventional and quantitative real-time PCR (RT-qPCR) technologies have the potential to reduce detection time in one to three days (Cheung \& Kam, 2012). One example was the commercial automated BAX ${ }^{\circledR}$-PCR system (Dupont Qualicon, USA), that reduces the enrichment steps, the risk of contamination by PCR amplicons and the demand for laboratory resources because is automated and eliminate the need for gel electrophoresis. The BAX ${ }^{\circledR}$ system combined all the essential PCR reagents, such as DNA polymerase, nucleotides, primers, internal positive control, and fluorescent dye (SybrGreen), into a single small lyophilized pellet in each PCR tube, to which the sample cultures could be added. The melting curve profiles showing Salmonella-specific temperature peaks could also eliminate the possibility of getting false positive results (Cheung \& Kam, 2012). Despite the advantages of methods based on DNA amplification, such as high specificity and sensitivity, degradation of the target DNA sequence and the presence of food interference, including fat and calcium (Glynn et al., 2006), might impair the performance of these methods. Alternative methods also included those immunoassay-based techniques, such as, the VIDAS ${ }^{\circledR}$ Salmonella assay (bioMérieux, France) that can produce negative results in one to three days. Despite of require onerous commercial kits and sophisticated equipments, the alternative methods present high productivity and quality of results and the cost effective should be considered mainly by testing laboratories that analyze samples routinely for foodborne pathogens. Some of these rapid methods have already been validated and accepted by international authorities as standard methods and have become increasingly popular among testing laboratories (Cheung \& Kam, 2012). Although rapid methods are efficient, with many containing protocols that have already been validated, these methods are still used as presumptive tests. Moreover, in cases where a pathogen is detected, the conventional method must be used for confirmation (Jasson et al., 2010). The aim of this study was to evaluate two rapid methods and compare them with the conventional method to detect Salmonella in artisanal Minas cheese samples.

\section{Materials and Methods}

\subsection{Microbiological Analysis}

A total of 63 samples of artisanal Minas cheese from different manufacturers and with different maturation times were collected in the region of Serro, Minas Gerais, Brazil. The BAX ${ }^{\circledR}$-PCR method from Qualicon DuPont, Wilmington, USA (AOAC Official Method 2003.09) and the immunoassay VIDAS ${ }^{\circledR}$-SLM method from bioMérieux, Marcyl'Etoile, France (AOAC Official Method 2004.03) were compared with the conventional ISO 6579 method (2005), that include pre-enrichment, enrichment, selective and differential plating, biochemical and serological identification. The lactic acid bacteria were count on DeMan, Rugosa and Sharp (MRS) and total and thermotolerant coliforms was determined by Most Probable Number (MPN) (Downes \& Ito, 2001). Additional tests, such as Gram stain and catalase, were conducted to confirm the lactic acid bacteria count. All tests were performed on an analytical unit of $25 \mathrm{~g}$.

\subsection{Physical-chemical Evaluation}

Water activity (aw) was measured on an automated analyzer (Decagon Aqualab CX-2, Washington, USA). Determination of salt, $\mathrm{pH}$ and acidity was according to Richardson (1985).

\subsection{Statistical Analysis}

We evaluated the performance attributes of rapid methods such as sensitivity, specificity, accuracy, false positives, and false negatives. The analyses were performed using the Epi-Info software (1993). The following definitions were used: 


$$
\begin{gathered}
\text { Sensitivity }=\frac{\mathrm{N}^{\circ} \text { of samples positive by conventional method }- \text { false negative }}{\text { Total of positive samples for the conventional method }} \times 100 \% \\
\text { Specificity }=\frac{\mathrm{N}^{\mathrm{o}} \text { of samples negative by conventional method }- \text { false positive }}{\text { Total of negative samples for the conventional method }} \times 100 \%
\end{gathered}
$$

Accuracy $=\frac{\mathrm{N}^{\mathrm{o}} \text { of sample positive by conventional method }- \text { false negative }+\mathrm{N}^{\mathrm{o}} \text { of sample negative byconventional method-false positive }}{\text { Total of samples }} \times 100 \%$

\section{Results and Discussion}

The contamination of artisanal cheeses by Salmonella is commonly reported and its occurrence varies (Kousta, Mataragas, Skandamis, \& Drosinos, 2010; Hall \& French, 2011). In the present survey, Salmonella was not detected by the ISO 6579 or PCR-BAX ${ }^{\circledR}$ methods in all 63 artisanal Minas cheese analyzed. However, VIDAS $^{\circledR}$-SLM immunoassay method indicated two samples contamined with Salmonella and this represent $3.17 \%$ of false positives (Table 1). Regardless this result, VIDAS ${ }^{\circledR}$-SLM showed high values of specificity and accuracy (Table 1). Both alternative methods PCR-BAX ${ }^{\mathbb{B}}$ and VIDAS ${ }^{\circledR}$ significantly decreased the time to obtain results compared to the standard ISO method and this is an important factor in the selection of an analytical method.

Reports on the comparison of performance between the PCR-BAX ${ }^{\circledR}$ and other analytical methods, included the immunoassay-based and the standard culture methods, for Salmonella detection are available. The PCR-BAX ${ }^{\circledR}$ method was able to detect low contamination by Salmonella sp. in cheese, orange juice and fish samples with a sensitivity of $76 \%, 95 \%$ and $98 \%$, respectively (AOAC, 2005). According to Cheung and Kam (2012), the comparison between the $\mathrm{BAX}^{\circledR}$ system, the immunoassay and the standard culture methods, for Salmonella detection showed that the $\mathrm{BAX}^{\circledR}$ system has very low false-positive and false-negative rate and generated results comparable with those of the standard culture methods. Other studies have also reported results regarding the efficiency of PCR-based methods (Tapchaisri et al., 1999; Von Rückert et al., 2008, Prendergast et al., 2012; Mcguinness, Barry, \& O’Grady, 2012).

Table 1. Comparison of conventional versus rapid methods for detection of the Salmonella sp. in samples units of Minas Traditional cheese

\begin{tabular}{lll}
\hline Number of sample & VIDAS $^{\circledR}$-SLM & PCR-BAX $^{\circledR}$ \\
\hline Total & 63 & 63 \\
Positive by conventional method & 0 & 0 \\
Positive by rapid method & 2 & 0 \\
Negative by conventional method & 63 & 63 \\
Negative by rapid method & 61 & 63 \\
False positive & 2 & 0 \\
False negative & 0 & 0 \\
Sensitivity (\%) & $\mathrm{Nd}^{*}$ & $\mathrm{Nd}$ \\
Specificity (\%) & 96.83 & 100 \\
Accuracy (\%) & 96.83 & 100 \\
\hline $\mathrm{Nd}^{*}=$ Not determined & &
\end{tabular}

Sensitivity = Number of samples positive by conventional method - false negative/Total of positive samples for the conventional method $\mathrm{x} 100$

Specificity $=$ Number of samples negative by conventional method - false positive/Total of negative samples for the conventional method $\mathrm{x} 100$

Accuracy $=($ Number of samples positive by conventional method - false negative $)+($ Number of samples negative by conventional method - false positive)/Total of samples x 100 
The sensitivity and specificity values observed for the VIDAS ${ }^{\circledR}$-SLM method differ from those found in literature for other foods with low natural contamination rates, such as milk powder, raw pork, chocolate milk, casein (AOAC, 2005), and chicken carcasses (Von Rückert et al., 2008). A good correlation (97.5\%) between a VIDAS $^{\circledR}$-SLM assay test and conventional culture technique were obtained when bulk tank milk and in-line milk filters were analyzed with the advantages of taking less time to obtain a negative or presumptive positive result (Walker, Kinde, Anderson, \& Brown, 2001). Analysis of food surface using VIDAS ${ }^{\mathbb{B}}$-SLM revealed lower false positives rates of $1.56 \%$ (Yeh, Tsai, Chen, \& Liao, 2002). The occurrence of false positive results may depend on the specificity of the antibody, which may present cross-reactions with correlated antigens. However, a recent report on the use of VIDAS ${ }^{\circledR}$ for screening raw meat and by-products from pork and beef showed that the number of positive samples detected was two-fold higher than that by culture method (Meyer, Thiel, Ullrich, \& Stolle, 2010).

The presence of coliform bacteria and high number of lactic acid bacteria in cheeses made from raw milk (Table 2) can impair the recovery of pathogens and compromise results. High microbial loading was expected in artisanal products that were manufacturing without the observation of good manufactured practices (GMP) and among this diverse contamination, some could promote the pathogens inhibition. In fact, De Medici et al. (1998) have observed that the presence of competing microbiota $\left(6.0 \times 10^{6} \mathrm{CFU} \mathrm{mL}^{-1}\right.$ of Citrobacter freundii) and low amounts (ranging from 1 to $2 \mathrm{CFU} \mathrm{mL}^{-1}$ ) of Salmonella sp. generated false negative results by VIDAS ${ }^{\circledR}$-ICS. Low number of Salmonella Enteritidis, ca 2.5 to $3.0 \log$ CFU mL ${ }^{-1}$, was detected in raw milk only when counting of endogenous microbiota was below $5.5 \log \mathrm{CFU} \mathrm{mL}{ }^{-1}$ (Nero, Matos, Barros, Beloti, \& Franco, 2009a). In vitro antagonistic activity of natural microbiota isolated from raw milk or from Minas artisanal cheese against Salmonella sp. was demonstrated (Alexandre, Silva, Souza, \& Santos, 2002; Nero et al., 2009b).

Table 2. Lactic acid bacteria and coliforms in Minas Traditional cheese

\begin{tabular}{ll}
\hline Endogenous microbiota & Log CFU or MPN g ${ }^{-1}($ Mean \pm SD) \\
\hline Lactic acid bacteria $\left(\log \mathrm{CFU} \cdot \mathrm{g}^{-1}\right)$ & $7.3 \pm 0.9$ \\
Total coliform $\left(\log\right.$ MPN.g $\left.\mathrm{g}^{-1}\right)$ & $2.2 \pm 1.6$ \\
Thermotolerant coliform $\left(\log\right.$ MPN.g $\left.{ }^{-1}\right)$ & $1.6 \pm 1.3$ \\
\hline
\end{tabular}

In addition to the endogenous microbiota of lactic bacteria and coliforms, the physicochemical properties of artisanal cheeses such as water activity, low $\mathrm{pH}$, acidity and high percentages of $\mathrm{NaCl}$ (Table 3) can minimize pathogens growth, provide cellular injury and hamper the recovery strategies.

Table 3. Physical-chemical characteristics of Minas Traditional cheese

\begin{tabular}{ll}
\hline Physical-chemical parameters & Mean $\pm \mathrm{SD}$ \\
\hline Water activity (Aw) & $0.886 \pm 0.037$ \\
$\mathrm{pH}$ & $5.607 \pm 0.503$ \\
Titratable acidity (\% lactic acid) & $1.056 \pm 0.330$ \\
Salt $(\% \mathrm{NaCl})$ & $0.806 \pm 0.315$ \\
\hline
\end{tabular}

The results obtained in this study using different methods indicated absence of Salmonella in samples of artisanal Minas cheese made with raw milk, even though much of producers did not attempt to GMP. However, attention should be paid to an inappropriate interpretation of these results, once it is necessary to evaluate if these methods allow maximally resuscitation and recover low numbers of sublethally injured cells. On the other hand, our results may contribute to further detailed evaluations and validations of alternative techniques with different food matrices before they could be accepted as cost-effective and standard methods for Salmonella testing in the future.

\section{Acknowledgements}

The authors thank to FAPEMIG (Minas Gerais State Science Funding Agency) for providing funding for this project. 


\section{References}

Alexandre, D. P., Silva, M. R., Souza, M. R., Santos, W. L. M. (2002). Atividade antimicrobiana de bactérias lácticas isoladas de queijo-de-Minas artesanal do Serro (MG) frente a micro-organismos indicadores. Arquivos Brasileiros de Medicina Veterinária e Zootecnia, 54(4), 424-428. http://dx.doi.org/10.1590/S0102-09352002000400014

AOAC. (2005). Official Methods of Analysis of AOAC International, $18^{\text {th }}$ ed., Gaithersburg, Maryland: AOAC International.

Brazil. (2001). Ministério da Saúde. Resolução n. 12 de 2 de janeiro de 2001. Aprova o Regulamento Técnico sobre padrões microbiológicos para alimentos. Diário Oficial [da] República Federativa do Brasil. Brasília, 10 January 2001. Seção I. p. 45-53.

Cheung, P. Y., \& Kam, K. M. (2012). Salmonella in food surveillance: PCR, immunoassays, and other rapid detection and quantification methods. Food Research International, 45(2), 802-808. http://dx.doi.org/10.1016/j.foodres.2011.12.001

De Médici, D., Pezzotti, G., Marfoglia, C., Caciolo, D., Foschi, G., \& Orefi, L. (1998). Comparison between ICS-VIDAS, MSRV and standard cultural method for Salmonella recovery in poultry meat. $\begin{array}{lllll}\text { InternationalJournal of } & \text { Food }\end{array}$ http://dx.doi.org/10.1016/S0168-1605(98)00157-3

Directiva 92/46/EEC. (1992). Laying down the health rules for the production and placing on the market of raw milk, heat-treated milk and milk-based products.

Downes, F. P., \& Ito, K. (Eds.). (2001). Compendium of methods for the microbiological examination of foods. (pp. 357-380). Washington, District of Columbia: American Public Health Association.

Epi Info. (1993). A world processing, database and statistic program for epidemiology on microcomputers, version 6.04, Atlanta, Georgia: Centers for Disease Control and Prevention.

Glynn, B., Lahiff, S., Wernecke, M., Barry, T., Smith, T. J., \& Maher, M. (2006). Current and emerging molecular diagnostic technologies applicable to bacterial food safety. International Journal of Dairy Technology, 59(2), 126-139. http://dx.doi.org/10.1111/j.1471-0307.2006.00253.x

Hall, W. F., \& French, N. (2011). An assessment of available information on raw milk cheeses and human disease 2000-2010. Ministry of Agriculture and Forestry. Technical Paper $\mathrm{N}_{\mathrm{o}}: 2011 / 58$.

International Standards Organization. ISO 6579. (2005). Microbiology of food and animal feeding stuffs horizontal method for the detection of Salmonella spp.

Jasson, V., Jacxsens, L., Luning, P., Rajkovic, A., \& Uyttendaele, M. (2010). Alternative microbial methods: an

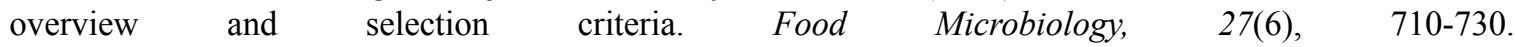
http://dx.doi.org/10.1016/j.fm.2010.04.008

Kousta, M., Mataragas, M., Skandamis, P., \& Drosinos, E. H. (2010). Prevalence and sources of cheese contamination with pathogens at farm and processing levels. Food Control, 21(6), 805-815. http://dx.doi.org/10.1016/j.foodcont.2009.11.015

Koyuncu, S., Andersson, M. G., \& Häggblom, P. (2010)Accuracy and sensitivity of commercial PCR-based methods for detection of Salmonella enterica in feed. Applied and Environmental Microbiology, 76(9), 2815-2822. http://dx.doi.org/10.1128/AEM.02714-09

Malorny, B., Tassios, P. T., Radström, P., Cook, N., Wagner, M., \& Hoorfar, J. (2003). Standardization of diagnostic PCR for the detection of foodborne pathogens. International Journal of Food Microbiology, 83(1), 39- 48. http://dx.doi.org/10.1016/S0168-1605(02)00322-7

Mcguinness, S., Barry, T., \& O'Grady, J. (2012). Development and preliminary validation of a real-time RT-PCR based method targeting tmRNA for the rapid and specific detection of Salmonella. Food Research International, 45(2), 989-992. http://dx.doi.org/ 10.1016/j.foodres.2010.08.012

Meyer, C., Thiel, S., Ullrich, U., \& Stolle, A. (2010). Salmonella in raw meat and byproducts from pork and beef. Journal of Food Protection, 73(10), 1780-1784.

Nero, L. A., Mattos, M. R., Barros, M. A. F., Beloti, V., \& Franco, B. D. G. M. (2009a). Interference of raw milk autochthonous microbiota on the performance of conventional methodologies for Listeria monocytogenes and Salmonella spp. detection. Microbiology Research, 164(5), 529-535. 
http://dx.doi.org/10.1016/j.micres.2007.04.003

Nero, L. A., Mattos, M. R., Beloti, V., Barros, M. A. F., Ortolani, M. B. T., \& Franco, B. D. G. M. (2009b). Autochthonous microbiota of raw milk with antagonistic activity against Listeria monocytogenes and Salmonella Enteritidis. Journal of Food Safety, 29(2), 261-270. http://dx.doi.org/10.1111/j.1745-4565.2009.00155.x

Oslen, J. E. (2000). DNA-based methods for detection of food-borne bacterial pathogens. Food ResearchInternational, 33(3-4), 257-266. http://dx.doi.org/10.1016/S0963-9969(00)00045-4

Prendergast, D. M., Dono, G., Mccann, A., Mc-Cabe, E., Fanning, S., Egan, J., Fanning, J., \& Gutierrez, M. (2012). Application of PCR for rapid detection and serotyping of Salmonella spp. from porcine carcass swabs following enrichment in semi-solid agar. Food Research International, 45(2), 993-999. http://dx.doi.org/10.1016/j.foodres.2010.08.013

Randazzo, C. L., Caggia, C., \& Neviani, E. (2009). Application of molecular approaches to study lactic acid bacteria in artisanal cheeses. Journal of Microbiological Methods, 78, 1-9. http://dx.doi.org/10.1016/j.mimet.2009.04.001

Richardson, G. H. (Ed.). (1985). Standard methods for the examination of dairy products, $15^{\text {th }}$ ed, American Public Health Association, Washington, District of Columbia.

Scallan, E., Hoekstra, R. M., Angulo, F. J., Tauxe, R. V., Widdowson, M-A, Roy, S. L., et al. (2011). Foodborne illness acquired in the United States-major pathogens. Emerging Infectious Disease, 17(1), 7-15.

Tapchaisri, P., Wangroongsarb, P., Panbangred, W., Chongsa-Nguan, M., Srimanote, P., Kurazono, H., Hayashi, H., \& Chaicumpa, W. (1999). Detection of Salmonella contamination in food samples by dot-ELISA, DNA amplification and bacterial culture. Asian and Pacific Journal of Allergy Immunology, 17(1), 41-51.

Vanne, L., Karwoski, M., Karppinen, S., \& Sjiiberg, A. M. (1996). HACCP-based food quality control and rapid detection methods for microorganisms. Food Control, 7(6), 263-276. http://dx.doi.org/10.1016/S0956-7135(96)00064-3

Von Rückert, D. A. S., Pinto, P. S. A., Vanetti, M. C. D., Moraes, M. P., Silva-Junior, A., \& Nero, L. A. (2008). Assessment of conventional detection method, immunoanalysis and polymerase chain reaction for Salmonella spp. monitoring in chicken. Journal of Rapid Methods and Automation in Microbiology, 16(2), 185-195. http://dx.doi.org/10.1111/j.1745-4581.2008.00125.x

Walker, R. L., Kinde, H., Anderson, R. J., \& Brown, A. E. (2001). Comparison of VIDAS Enzyme-linked Fluorescent Immunoassay using Moore swab sampling and conventional culture method for Salmonella detection in bulk tank milk and in-line milk filters in California dairies. International Journal of Food Microbiology, 67(1-2), 123-129. http://dx.doi.org/10.1016/S0168-1605(01)00427-5

West, H. G. (2008). Food fears and raw-milk cheese. Appetite, 51, 25-29. http://dx.doi.org/10.1016/j.appet.2008.02.004

Yeh, K. S., Tsai C. E., Chen S. P., \& Liao, C. W. (2002). Comparison between VIDAS Automatic Enzyme-Linked Fluorescent Immunoassay and culture method for Salmonella recovery from pork carcass sponge samples. Journal of Food Protection, 65(10), 1656-1659. 